\title{
PReS-FINAL-2123: Feto-maternal outcome in patients with systemic sclerosis
}

\author{
SE Maher ${ }^{1 *}$, FM Ismail ${ }^{2}$ \\ From 20th Pediatric Rheumatology European Society (PReS) Congress \\ Ljubljana, Slovenia. 25-29 September 2013
}

\section{Introduction}

Progressive systemic sclerosis is a life threating disease typically involve the heart, lungs, and other organs. pregnancy is a stressful condition that can affect the course of the disease.

\section{Objectives}

To study the maternal and fetal outcomes in pregnant women with Systemic Sclerosis (ssc) and to analyze the possible associated risk factors.

\section{Methods}

Twenty pregnant women with ssc and twenty agematched low risk pregnant women were recruited in this study. Patients were evaluated clinically and laboratory at the entry of the study and at monthly intervals. Different pregnancy outcome measures were studied. Impacts of pregnancy on scleroderma patients were determined during and after pregnancy. The possible associated risk factors were analyzed.

\section{Results}

Twenty ssc pregnant women were recruited in this study with a mean age $29.6 \pm 3$. Eight $(40 \%)$ of them had limited ssc, and twelve (60\%) had diffuse type. Pregnancies were complicated by maternal flare of underlying disease in six (30\%) pregnant patients. Six patients (30\%) had preterm labor. Four patients $(20 \%)$ had small for gestational age (SGA) infants, two of them (10\%) had intra uterine growth retardation (IUGR). Two patients $(10 \%)$, with diffuse type, fulfilled criteria of antiphospholipid syndrome (APS) but unfortunately the pregnancy ended in miscarriage. Eight (40\%) full-term infants were born two of them were SGA, 2 cases with miscarriage due to renal crisis and pulmonary

${ }^{1}$ Pediatric, El Minia University, Minia, Egypt

Full list of author information is available at the end of the article hypertension and another two cases with intra uterine fetal death (IUFD). The live birth rate was 14/20 (70\%) in ssc group.

\section{Conclusion}

Women with ssc can safely have healthy pregnancies if pregnancy is planned when the disease is stable and managed by a multidisciplinary team during pregnancy.

\section{Disclosure of interest}

None declared.

\section{Authors' details}

${ }^{1}$ Pediatric, El Minia University, Minia, Egypt. ${ }^{2}$ Rheumatology, El Minia University, Minia, Egypt.

Published: 5 December 2013

doi:10.1186/1546-0096-11-S2-P135

Cite this article as: Maher and Ismail: PReS-FINAL-2123: Feto-maternal outcome in patients with systemic sclerosis. Pediatric Rheumatology 2013 11 (Suppl 2):P135.

Submit your next manuscript to BioMed Central and take full advantage of:

- Convenient online submission

- Thorough peer review

- No space constraints or color figure charges

- Immediate publication on acceptance

- Inclusion in PubMed, CAS, Scopus and Google Scholar

- Research which is freely available for redistribution 